\title{
Employee involvement in reducing alienation in Russian environmental corporations
}

\author{
Elena Kozlova ${ }^{1, *}$ \\ ${ }^{1}$ Chelyabinsk State University, 129, Br.Kashirinykh Str., 454001, Chelyabinsk, Russia
}

\begin{abstract}
Sustainable development, encompassing environmental, social responsibility, and corporate governance issues, is a crucial development concept for many global companies. Foreign companies have long appreciated the positive economic effect of following these principles, which consists of an increase in key indicators and a decrease in staff turnover. Russian companies still consider sustainable development activities an optional element of doing business and do not expect additional economic benefits. Current economic conditions are characterized by high uncertainty and dynamism, which forces companies to look for new ways to improve business efficiency. In Russian companies, one of these ways may be to reduce employees' degree of alienation and increase employee engagement. Based on the survey results, the article analyzes the social and personal factors that affect the degree of alienation of employees of Russian enterprises. It is proposed to consider increasing employees' engagement as an effective mechanism for reducing the level of alienation. The practice of assessing employee engagement in Russian companies is considered.
\end{abstract}

\section{Introduction}

Corporations play a key role in implementing sustainable development strategies. In the past few years, there has been increased public and stakeholder attention to enterprises' role in implementing sustainable development strategies. Although the most significant transnational companies play a crucial role in their implementation, the role of small and medium-sized businesses is growing every year. One of the main factors influencing the change in business behavior in sustainable development is the improvement of the company's reputation. The information dissemination in the development of the global information space and social networks leads to an increase in its importance in the public, shareholders, and investors' eyes. Solving social and environmental problems by small and large companies leads to increased transparency in corporate activities. The strategic goals of corporations in sustainable development affect not only environmental issues but also social support for employees and concern employees' health and safety. The engagement of employees in implementing the concept of sustainable development significantly increases its effectiveness and competitiveness. Simultaneously, the attractiveness of companies among young workers who share the principles of sustainable development increases

${ }^{*}$ Corresponding author: kozlova@csu.ru 
significantly. Significant attention in Russian companies is paid to human capital $[1,2]$, as to one of the critical resources, and environmental issues.

The alienation of workers remains one of the crucial problems associated with hired labor. An employee's alienation can manifest itself at various levels - from the labor process, the results of labor, the team, and himself. M. Seeman [3] considers alienation a multidimensional concept that manifests itself in various versions: self-estrangement, isolation, powerlessness, normlessness and meaninglessness. Seeman considered the social conditions for the emergence of all forms of manifestation of alienation and also tried to establish their behavioral consequences. D. Dean [4], when studying alienation, suggested identifying only three of its types - powerlessness, normlessness, and social isolation. He assessed each of them on a scale that can be combined to obtain a cumulative assessment of alienation. According to the approach of S. R. Maddi, S.C. Kobasa, and M. Hoover [5], alienation should be viewed in conjunction with the loss of meaning and manifests itself in four primary forms: vegetativeness, impotence, nihilism, adventurism. The questionnaire developed by them assesses the severity of each of the forms concerning various spheres of an individual's life - work, social life, interaction with other people and family, and himself.

An increase in alienation level leads to a decrease in labor productivity, which entails a decrease in production efficiency. Overcoming the alienation of workers occurs by increasing their engagement, which is one of the most critical aspects of sustainable development. The issue of studying employee engagement is based on the study by W. Kahn [6], who identified three aspects of engagement - cognitive (beliefs about the organization, its leaders, and working conditions), emotional (positive or negative attitudes toward the organization, and its leaders) and physical ( physical energies exerted by individuals to accomplish their roles). Among the personal characteristics of the engagement, W. Kahn noted meaningfulness, safety and availability. Employee engagement was higher in the case of greater psychological meaningfulness, psychological safety, and psychological availability. Among other personal characteristics, it is also worth noting psychological stability, despite the difficulties arising in the performance of work A. Bakker [7]. D. May, R. Gilson and L. Harter [8], engagement is related to the concept of job engagement, which characterizes the degree to which an individual realizes his job role. When they tested Kahn's assumptions, they found that meaningfulness, safety, and availability are significantly related to engagement and that employee performance is highly dependent on it. However, engagement is often associated with characteristics such as emotional experiences and wellbeing.

M. Christian, A. Garza and J. Slaughter [9] defined work engagement as a relatively enduring state of mind referring to the simultaneous investment of personal energies in work experience or performance. At the same time, work engagement should refer to a psychological connection with the performance of work tasks rather than an attitude toward the organization's features or the job. Engagement represents a commonality among physical, emotional, and cognitive energies that individuals bring to their work role. An important factor in defining engagement is its conceptualization as a "state" versus as a "trait." That is, engagement can vary over time and should not be considered a stable trait. Christian, Garza and Slaughter point out that engagement is a unique construct, and there are significant differences between job satisfaction, organizational commitment, job engagement and work engagement. The study found that an engaged workforce will likely perform their tasks more efficiently and effectively.

According to A. Saks [10], employee engagement is based on the exchange theory (SET). The relationship between the employee and the organization transforms over time into mutual obligations. Employees are willing to give away their capital (emotional, cognitive and physical) in exchange for company resources. However, engagement should be distinguished from organizational commitment, which characterizes an individual's 
attitude to an organization and the realization of his role as a member. In doing so, engagement and organizational commitment will depend on employees' perceived support. The employees involved are characterized by higher labor productivity, but, without organizational commitment to a particular organization, one should expect them to be focused on improving the effectiveness of their professional activities in any organization that offered the best conditions, without sharing the company's key values, such employees do not take an active part in its development. Thus, improving the company's efficiency is possible provided that employees are involved and share the organization's goals and core values [11].

\section{Materials and methods}

The analysis of the degree of alienation was carried out based on a survey of Russian enterprises' employees in October 2020. The survey involved workers and managers of Russian enterprises between 18 and 65, living in more than 18 Russian cities. To analyze the degree of alienation of workers in Russian enterprises, we used the methodology [10], based on assessing the degree of respondents' agreement with statements characterizing the various components of alienation. Four key components of alienation were analyzed: 1) self-estrangement / self-fulfillment; 2) powerlessness / power; 3) isolation / incorporation; 4) meaninglessness / meaningfulness. Four statements matched each component of alienation. The respondent's degree of agreement with them was transformed into quantitative estimates from 0 to 1 , where the highest values correspond to a higher degree of alienation. The final degree of alienation of the $i$-th respondent was estimated by the formula (1):

$$
L_{i}^{a l}=\frac{1}{16} \sum_{j=1}^{4} \sum_{k=1}^{4} A_{i j k}
$$

where $A_{i j k}=\{0 ; 1 / 4 ; 1 / 2 ; 3 / 4 ; 1\}-$ a numerical characteristic of the answer of the i-th respondent to the $\mathrm{k}$-th question related to the disclosure of the $\mathrm{j}$-th component of alienation.

Based on the z-criterion [11], to assess the difference between the shares of a feature, an assessment of the differences between two shares of a feature in general populations is carried out. The null hypothesis $\mathrm{H} 0$ is that the shares of the trait in the populations are the same. Test $\mathrm{z}$-statistics are used to test the null and alternative hypotheses (2):

$$
Z=\frac{\left(p_{s 1}-p_{s 2}\right)-\left(p_{1}-p_{2}\right)}{\sqrt{\bar{p}(1-\bar{p})\left(\frac{1}{n_{1}}+\frac{1}{n_{2}}\right)}}
$$

where $p_{\mathrm{s} 1}$ and $\mathrm{p}_{\mathrm{s} 2}$ are the shares of "successes" in each sample, $\mathrm{n}_{1}$ and $\mathrm{n}_{2}$ are the sample sizes, $\bar{p}$ is the estimate of the share of successes in the combined general population, $\mathrm{p}_{1}$ and $\mathrm{p}_{2}$ are the general shares of the feature.

To analyze the engagement of Russian corporations' engagement, we analyzed the information posted on the 30 largest Russian companies' official websites from the Expert400 rating for 2020 (https://expert.ru). The analysis of the availability of annual reports in the field of sustainable development of companies on the official website was carried out and the use of methods for assessing the degree of engagement of company employees. The information was obtained from open Internet sources - the company's official websites and documents posted on them.

\section{Results}

In the course of the analysis, it was found that the degree of alienation of workers in large enterprises is lower than in small and medium-sized enterprises (fig.1, tab.1). 


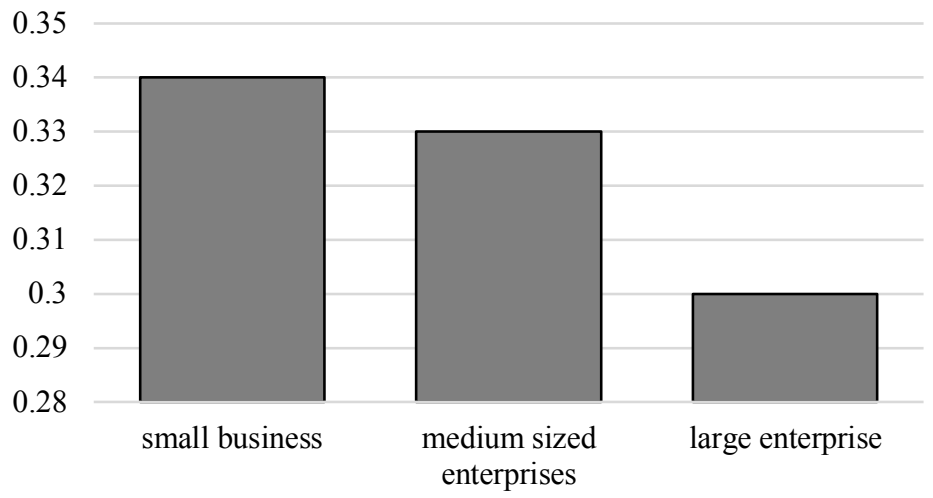

Fig. 1. Mean of alienation degree of employees of Russian enterprises.

Table 1. Central Tendency of employee alienation.

\begin{tabular}{|c|c|c|c|c|c|}
\hline Size & Mean & S.E. & Me & $\mathbf{Q}_{\mathbf{1}}$ & $\mathbf{Q}_{\mathbf{3}}$ \\
\hline Small business & 0,338 & 0,017 & 0,344 & 0,25 & 0,422 \\
\hline $\begin{array}{c}\text { Medium sized } \\
\text { enterprises }\end{array}$ & 0,331 & 0,014 & 0,344 & 0,25 & 0,438 \\
\hline $\begin{array}{c}\text { Large } \\
\text { enterprise }\end{array}$ & 0.304 & 0.016 & 0.328 & 0,172 & 0,422 \\
\hline
\end{tabular}

The z-test was used to assess the influence of social and organizational factors on the degree of alienation of Russian corporations' employees (Table 2). Among the organizational factors influencing the degree of alienation, it is worth noting the change in wages over the past year. Thus, employees whose salaries have increased (to a significant or insignificant extent) demonstrate less alienation. To a greater extent, workers whose wages for the previous year have remained unchanged are prone to alienation. For employees who have noted a change for the better in the organization's informal situation over the past year, there is also a lower degree of alienation compared to other employees. Besides, the most alienated, compared to other cities, are employees of Moscow companies. Among the social factors, it is worth noting the respondent's marital status and children's presence. Thus, married workers show less alienation, as do workers with one or more children.

Table 2. Factors influencing the alienation degree.

\begin{tabular}{|l|c|}
\hline \multicolumn{1}{|c|}{ Factors } & $\mathbf{Z}$ \\
\hline \multicolumn{1}{|c|}{ 1. Organizational } \\
\hline Wage: & $2.407^{* *}$ \\
\hline - increased significantly & $2.230^{* *}$ \\
\hline - slightly increased & $-3.289^{*}$ \\
\hline - has not changed & $2.586^{*}$ \\
\hline Changing the informal position in the organization: \\
\hline - changed in a favorable direction \\
\hline Company location: & $-9.430^{*}$ \\
\hline - Moscow 2 Social & \\
\hline \multicolumn{2}{|c|}{} \\
\hline Family status: & $2.594^{*}$ \\
\hline - married & $2.772^{*}$ \\
\hline Having children
\end{tabular}

Confidence level: ${ }^{*}-0.01,{ }^{* *}-0.05,{ }^{* * *}-0.10$ 
An analysis of the 30 largest Russian companies' official websites showed that the sustainability report was posted by 23 companies (Table 3). Simultaneously, several companies that do not submit an annual sustainability report post information on their compliance with certain sustainable development principles on their official website (Aeroflot, Rosatom, NLMK Group).

Information on assessing personnel engagement, measuring its level and analyzing dynamics is provided on the websites and in the sustainability reports of only 10 companies (Table 3). On the official websites of another 10 companies, information about employee engagement is mentioned without specifying the methodology for assessing it and changing its level over time. Among the main indicators for assessing employee engagement is loyalty to the company and sharing its values, readiness to realize one's potential and a high level of trust.

Table 3. Sustainable Development Report and Employee Engagement Assessment in Russian corporations.

\begin{tabular}{|c|c|c|c|}
\hline Company & $\begin{array}{l}\text { Sustainable } \\
\text { Development } \\
\text { Report }\end{array}$ & $\begin{array}{c}\text { Employee } \\
\text { Engagement } \\
\text { Assessment }\end{array}$ & Details \\
\hline Rosneft & + & & \\
\hline Lukoil & + & & \\
\hline Gazprom & + & + & $\begin{array}{l}\text { Key drivers of engagement: trust in top } \\
\text { management; commitment to the Company; } \\
\text { high awareness. }\end{array}$ \\
\hline $\begin{array}{c}\text { Sberbank of } \\
\text { Russia }\end{array}$ & + & + & $\begin{array}{l}\text { Annual assessment of the engagement index: } \\
\text { pride in the Bank, assessment of the Bank as } \\
\text { an employer, identification with the Bank at } \\
\text { the level of goals, values and future, and how } \\
\text { the Bank encourages employees to work at } \\
\text { their maximum potential. }\end{array}$ \\
\hline $\begin{array}{c}\text { Russian } \\
\text { Railways }\end{array}$ & + & & \\
\hline Surgutneftegas & - & & \\
\hline Rostec & + & & \\
\hline $\begin{array}{l}\text { X5 Retail } \\
\text { Group }\end{array}$ & + & & \\
\hline Magnit & + & & \\
\hline Safmar group & - & & \\
\hline VTB & + & + & $\begin{array}{c}\text { Engagement assessment includes: } \\
\text { understanding the strategic goals, mission, } \\
\text { vision and value of VTB Group, willingness } \\
\text { to make additional efforts to achieve the set } \\
\text { goals and having the necessary resources for } \\
\text { this. }\end{array}$ \\
\hline Rosatom & - & & \\
\hline Transneft & + & & \\
\hline Inter RAO & + & & \\
\hline Rosseti & + & & \\
\hline Tatneft & + & & \\
\hline Norilsk Nickel & + & + & $\begin{array}{l}\text { Engagement survey "Hear everyone" in the } \\
\text { form of employee questionnaires on crucial } \\
\text { issues }\end{array}$ \\
\hline Novatek & + & & \\
\hline Evraz & + & + & $\begin{array}{l}\text { Engagement indicators: the employee speaks } \\
\text { positively about the company, wants to stay } \\
\text { (continue working in the company), makes }\end{array}$ \\
\hline
\end{tabular}




\begin{tabular}{|c|c|c|c|}
\hline & & & efforts to achieve the company's success \\
\hline $\mathrm{EN}+$ & + & + & $\begin{array}{l}\text { Annual staff satisfaction surveys and regular } \\
\text { surveys. }\end{array}$ \\
\hline $\begin{array}{l}\text { Megapolis } \\
\text { Group }\end{array}$ & - & & \\
\hline NLMK & - & & \\
\hline Aeroflot & - & & \\
\hline AFK Sistema & + & + & $\begin{array}{l}\text { Factors: trust in top management and a sense } \\
\text { of one's value for the company, the content } \\
\text { of the work, and the culture, values, mission } \\
\text { of the company, prospects and dynamism of } \\
\text { its development. }\end{array}$ \\
\hline Rusal & + & & \\
\hline UGMC Group & - & + & $\begin{array}{l}\text { Baseline engagement metrics: to what extent } \\
\text { the basic needs of employees are satisfied, } \\
\text { whether personnel management is supported, } \\
\text { whether teamwork is well established, } \\
\text { whether employees are satisfied with their } \\
\text { development. }\end{array}$ \\
\hline Sibur & + & + & $\begin{array}{l}\text { Employees express their wishes to the } \\
\text { enterprise management or the company as a } \\
\text { whole during an annual survey }\end{array}$ \\
\hline Severstal & + & + & $\begin{array}{l}\text { Questions: how clear are the Company's } \\
\text { strategic priorities, what should change in } \\
\text { employees' work, assessment of the degree } \\
\text { of acceptance and support of the new } \\
\text { strategy in the team. }\end{array}$ \\
\hline $\begin{array}{l}\text { Magnitogorsk } \\
\text { Iron and Steel } \\
\text { Works }\end{array}$ & + & & \\
\hline SUEK & + & & \\
\hline
\end{tabular}

\section{Discussion}

Enterprises are focused on the maximum use of employees' labor potential by creating the necessary conditions for its implementation. A decrease in the degree of alienation of workers in large enterprises is achieved by implementing many social programs and projects, including those with government support, which today is rarely implemented in small and medium-sized enterprises. Besides, at many large enterprises, the trade union's action is still strong, various mechanisms for the participation of workers in the company's management, and applying collective labor agreements. All this significantly reduces the level of alienation of employees of large companies compared to small ones. Analysis of the factors influencing the degree of alienation showed that organizational and personal ones are significant. A company can only exert a controlling influence on the first group of factors. At the same time, personal factors must be taken into account when assessing the level of alienation.

The critical factor that can influence the degree of alienation in any organization is increased employee engagement. A low level of personnel engagement becomes an obstacle to achieving key business goals and reduces its activities' efficiency. A low degree of employee engagement is characterized by job dissatisfaction, a lack of loyalty to the company, and a high degree of alienation. At the same time, the employees involved demonstrate loyalty to the company's values and the rules in force within the organization. Such employees should not be expected to violate agreements or actions to the detriment of 
the organization. The engagement of many employees guarantees the construction of effective business processes, a high level of trust between employees and initiative.

Despite significant attention from the public and investors to the observance of sustainable development principles by the largest companies in Russia, even the leading enterprises do not pay due attention to this issue. Some of companies explored partially adhere to sustainable development principles and still consider it wise to follow them only to create a favorable image and attract foreign investors. Despite the growing number of companies that include sustainability reporting elements in their annual reports, the development of internal documents and the preparation of full-fledged reports (taking into account international requirements and standards) is the result of a small number of Russian companies.

\section{Conclusion}

The problem of increasing employees' alienation and decreasing engagement is one of the critical issues in personnel management. Human capital, along with other types of it, is becoming a critical factor in sustainable development. Unlocking the potential of employees is possible with a low level of alienation and high personnel engagement. Involved employees work more efficiently and make every effort to achieve the company's goals, feeling their engagement in the overall result, and share corporate values. To increase engagement, the company must create conditions for employees to fulfill their professional goals successfully. The lack of a unified approach to assessing personnel engagement in Russian companies does not allow assessing the effectiveness of the methods used to compare specific enterprises.

\section{Acknowledgement}

The reported study was funded by RFBR, project number 20-010-00653.

\section{References}

1. D. Pletnev, M. Kazadayev, V. Barkhatov, E3S Web Conf. 157, 04028 (2020) https://doi.org/10.1051/e3sconf/202015704028

2. D. Pletnev, E. Nikolaeva, Country Experiences in Economic Development, Management and Entrepreneurship. Eurasian Studies in Business and Economics (Springer, Cham, 2017) https://doi.org/10.1007/978-3-319-46319-3_27

3. M. Seeman, On the Meaning of Alienation. American Sociological Review 24, 783791 (1957) http://doi.org/10.2307/2088565

4. D.G. Dean, American Sociological Review 26(5), 753-758 (1961) http://doi.org/10.2307/2090204

5. S. R. Maddi, S. C. Kobasa, M. Hoover, Journal of Humanistic Psychology 19(1), 7376 (1979) http://doi.org/10.1177/002216787901900407

6. W.A. Kahn, Academy of Management Journal 33(4), 692-724 (1990) http://doi.org/10.5465/256287

7. A.B. Bakker, Current Directions in Psychological Science 20(4), 265-269 (2011) http://doi.org/10.1177/0963721411414534

8. D.R. May, R.L. Gilson, L.M. Harter, Journal of Occupational and Organisational Psychology 77, 11-37 (2004) http://doi.org/10.1348/096317904322915892 
9. M.S. Christian, A.S. Garza, J.E. Slaughter, Personnel Psychology 64(1), 89-136 (2011) http://doi.org/10.1111/j.1744-6570.2010.01203.x

10. A.M. Saks, Journal of Managerial Psychology, 21(6), 600-619 (2006) http://doi.org/10.1108/02683940610690169

11. S.L. Albrecht, A.B. Bakker, J.A. Gruman, W.H. Macey, A.M. Saks, Journal of Organizational Effectiveness: People and Performance 2(1), 7-35 (2015) http://doi.org/10.1108/JOEPP-08-2014-0042

12. D.A. Pletnev, E.V. Kozlova, St. Petersburg State Polytechnical University Journal. Economics 13(3), 141-157 (2020) http://doi.org/1018721/JE.13311

13. R.C. Sprinthall, Basic Statistical Analysis (Pearson Education, 2011) 